\title{
ON THE WRITING SYSTEMS OF ANCIENT PERU: THE POSSIBILITY OF THE QUELLQA AND THE QUIPU AS AN INSTRUMENT OF POWER OF THE INCAS
}

\section{Tarmo Kulmar}

\begin{abstract}
The focus is laid on the role and significance of both the knot-script quipu and the hypothetical writing system quellqa in the governing of the Incan state, and also on the reasons why the Incas preferred the quipu to a more flexible system of writing. The author uses data from the chronicles of the period of Spanish conquest and views from scientific researchers.

It is probable that the use of quellqa was banned by the order of Inca Pachacutec Yupanqui or Inca Tupac Yupanqui around 1470 in connection with the subjugation of the powerful Chimú state in northern Peru and among its allies. The aim of the Incas was to prevent a wider spread of this system of information exchange, which was readily available and convenient to use.

In its stead, the Incas favoured the use of the traditional mnemotechnical device quipu, which was known to the previous civilisations in Peru, because its practical uses were limited. The teaching, learning, and use of the quipu were subjected to the strict control of a special organ of government. This served the political interests of the early totalitarian state.
\end{abstract}

Key words: Peru, Inca Empire, Kingdom Chimú, knot-script quipu, hypothetical writing system quellqa, early totalitarian state, social control

\section{INTRODUCTION}

No system of government can exist without transcribing verbal information. Therefore, a state requires for its existence a writing system as a means of recording and reproducing information. As far as is known, there has never existed a civilisation where such a means has not been used in one form or another.

An effectively functioning empire with a strong central power and wellorganised hierarchy of officials, the state of the Peruvian Incas was no exception in this respect. Usually, it is assumed that the Incas did not have a writing system in the traditional sense but only used a mnemotechnical statistics de- 
vice, a knot-script called quipu. However, both data from the chronicles and studies of the recent decades indicate that there was apparently some kind of pictorial or hieroglyphic system of writing used in ancient Peru.

Not all the views on the existence of an Incan writing system will be addressed below. The focus is laid on the role and significance of both the quipu and the hypothetical "another" writing system in the governing of the Incan state. The reasons why the Incas preferred the quipu to a more flexible system of writing will be discussed as well. The author uses data from the chronicles of the period of Spanish conquest and views by other scholars.

\section{THE LEGENDARY WRITING SYSTEM QUELLQA}

The chronicler Montesinos (1957: 60-62) has recorded a unique note that the Incas have had a period in history when they used a written script. Montesinos gives its Quechuan name, quellqa ${ }^{1}$ and adds that the Incas banned its use. In more detail, Montesinos describes the implementation of the ban. According to him, during the reign of Emperor Inca Tupac Kauri Pachacutec, a number of neighbouring states refused to submit to the rule of the Incas and put up tough resistance. Large-scale sacrificial rituals were carried out and the counsel of the oracle of Viracocha the God of Heaven was sought. The answer was unequivocal: the culprit was the script, which was to be banned. Tupac Kauri Pachacutec issued a law that banned, under the threat of death, the use of quellqas, which were written on parchments and the leaves of certain trees. After that the use of the quellqa ceased, and transfer was made to the quipu. The implementation of the law was observed so strictly that when some time later a scholar re-invented the script he was reportedly sentenced to death and burned alive. The issue of the quellqa has been subjected to more scrutiny, in particular by Carlos Radicati (1984: 11-60; Busto Duthurburu 1981: 203-206).

\section{THE POSSIBLE SOLUTION TO THE ISSUE OF THE QUELLQA}

Montesinos's chronicle is seen as exceptional among the others. Namely, it is the only one to present a lengthy list of the Incan rulers - a total of 104 rulers, although their total until the Spanish invasion was 12 . There is no ruler by the aforementioned name on the official historical list. On the other hand, Montesinos's account contains a number of circumstances that are not indicative of an invented story. Furthermore, an analysis of the chronicle reveals that the author's knowledge was profound. A comparison of Montesinos's account with 
the historical facts of the imperial period of the Incan state allows a hypothetical reconstruction of both the time and the possible cause of the event.

By the "Oracle of the God of Heaven" Montesinos probably means the national oracle seated in the town of Pachacamac on the Pacific coast. His existence is also referred to by other chroniclers, and, as far as is known, he was revered all across the empire.

Here we can go further with the discussion: The cultic centre of Pachacamac, situated in the Lurín Valley, the central coast of present-day Peru, apparently fell into the hands of the Incas by peaceful means under a treaty in the $1450 \mathrm{~s}$, when Tupac Yupanqui took command of the military campaign on the Pacific coast. In the Incan succession, there was a tradition to appoint the adult heir to the throne as either a vicegerent or the commander-in-chief of the army. For a long time, until the death of Pachacutec Yupanqui in 1471, his most capable son, Tupac Yupanqui, was indeed the co-regent, who also conquered the northern Chimú kingdom around 1470.

It is possible that the emperor and his heir apparent - Pachacutec Yupanqui and his son Tupac Yupanqui, who annexed the coastal territories - have blended in the account of Montesinos's source.

Chimú emerged on a territory that had been the cradle of the Mochica civilisation, which was named after the valley of the Moche River, a few hundred years earlier, in the second half of the first millennium AD. ${ }^{2}$ Mochica had a sharply stratified class society and a number of militant principalities. The high-quality pottery of Moche artisans is very impressive. The extant articles include a profusion of small round earthenware items with various pictographic signs on them (e.g., Berezkin 1983: 47-48). Pictographic signs have also been found on the earthenware of the Nazca civilisation, which existed in coastal areas somewhat more to the south and somewhat earlier in time (see Busto Duthurburu 1988: 169-190).

It is possible that the signs represent the pictographic writing system of the civilisations of the so-called classical period, the pre-Incan age, in Peru. In the first millennium $\mathrm{AD}$, the pictographs were written on earthenware or tablets. Later, during the Chimú state, they had been written on palm leaves, a material that was readily available, as is also narrated by Montesinos. Such organic material, however, could not survive in the humid climate of the coastal valleys of Peru - for instance, in the burial grounds of the Vicus civilisation not even human remains or textiles have been found. ${ }^{3}$ There is no archaeological evidence whatsoever for the use of parchment. Much more promising, however, is research on the abundance of textiles found in the burial sites and mountains of the arid areas to the south. Studies by Victoria de la Jara (1970a; 1970b) and Thomas Barthel (1977: 27-31) have shown that pictograms could be woven into fabrics. 
Thus, the author puts forward the hypothesis that around 1470 Pachacutec and Tupac came into contact with the writing system of the coastal civilisations current in the Chimú state. Why was it not introduced in the empire? First, in order to break the cultural continuity of the powerful Chimú and its allies, as this posed a threat to the imperial expansionist policies of the Incas. Second, the introduction of such a comfortable means of disseminating verbal information was not expedient to the Incas in domestic policy terms, for it would have encouraged the spread of free thinking and pluralism of ideas among the population and endangered the embryonic totalitarian regime. Therefore, it was politically more prudent to ban the use of such an easily learnable script altogether and promote instead the mnemotechnical statistics device quipu, the teaching and use of which was subjected to the central authority and was therefore strictly controllable.

It is also possible that by seeking the counsel of Pachacamac's oracle, the law to be enforced was given a duly proper religious justification. Furthermore, Pachacamac had been incorporated into the Incan state only recently. The situation of the local priesthood was still insecure and apparently they were forced to show loyalty with the answer that was expected from them by the presence of Tupac's occupying troops.

Consequently, an analysis of the note in Montesinos's chronicle allows the conclusion that, in principle, the account given may correspond to the historical reality.

\section{KNOT-SCRIPT QUIPU ${ }^{4}$}

The quipu (see Figs. 1-2) represented a bundle of cords, in which information was conveyed by the number, position and colour of the cords and the number, size and shape of the knots tied into the cords. A quipu consisted of the following elements: (1) the base cord, (2) subsidiary threads of different colour attached to it, (3) new subsidiary threads of different colour attached to them and (4) knots of different shapes and degrees of sophistication tied into them. Such a system allowed an enormous amount of different variations and combinations. For instance, a quipu found in Pachacamak's temple weighed six kilograms. Such a bundle of cords contained a wealth of information, which today could figuratively be compared to that accumulated into a bulky statistical reference work.

Quipus contained numerical, possibly also some conceptual data. It is possible that the quipu could even be used to record phonemes; unfortunately, the chronicles provide no information about that. Neither is much known about 
the techniques of data recording. It is known that knots normally served as units of calculation - one cord could have a maximum of 9 knots in it. A knot denoting a new position was already tied into a higher-ranking cord (the Incas used the decimal system in calculation). Above tens were hundreds, then came thousands, and so on. Apparently, also included in the same system were knots of a higher degree of sophistication, the meaning of which is unknown as yet.

Usually, a quipu recorded items of a concrete category. One category could include several types. In that case, the most important type occupied the first place. For instance, in the weapons category, long javelins as the most important weapons came first. They were followed by slingshots, then by close-combat arms - war batons and battle axes. The accounting of provisions started with maize, followed by potato. However, no information has come through to our day as to how the particular contents of a particular quipu were marked. Most likely, there were specific signs used to indicate the contents.

The chronicler Antonio de la Calancha (1976) says that specific symbols could be used in the quipu to mark personal and topographical names. It is highly probable that quipus were even employed as aids to remembering laws, historical accounts and other texts.

Thus, the quipu was used to record, preserve, forward and reproduce information reflecting all the activities of Incan life, primarily that which could be expressed numerically. This was done in compliance with a pre-established code that was effective in the entire empire. Possibly, the state statistics board constituted of a big depository of quipus, which were updated on a regular basis. The scope of a quipu was virtually unlimited. In principle, it is possible that the quipu was capable of conveying intricate conceptual constructions, representing thus a relatively universal means of communication.

The quipu only had value to a person trained to work with it. The arithmetic processing of the data was performed by an official named quipucamayoc, who manually encoded verbal information into knots. Another official was needed to manually decode the knots back into verbal information. The office of quipucamayoc was handed down along ancestral lines, or they were selected according to ability in their childhood and received appropriate training. A quipucamayoc was only allowed to err once; a second error made him a candidate for capital punishment. There were at least four quipucamayocs in each human settlement. They dealt with accounting and the storing of quipus. At the request of a special official they provided information as requested in each particular case. Each report was prepared in at least two copies, one of which was stored on the spot and the other was sent to a higher authority. Summarized data were sent to an ever higher authority, until they reached the sovereign's private secretary, whose title was Incap Quipucamayocnin Chillque Inca - the Chief of the Quipucamayocs. 


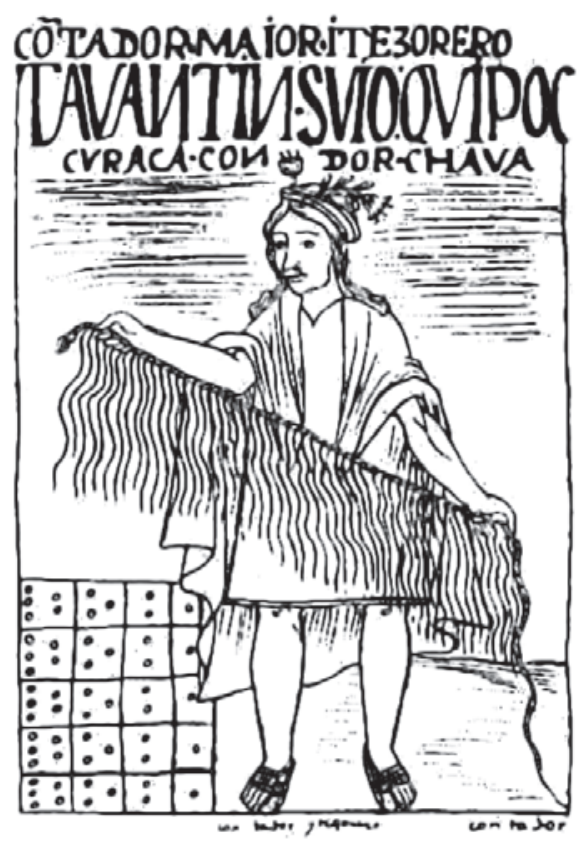

Figure 1. "Curaca Condor Chaua" chief accountant to the Inka (Guaman Poma de Ayala, F. 1980 [1613] Nueva Corónica y Buen Gobierno del Perú, J. V. Murra y R. Adorno (eds.), 3 vols.. México City: Siglo XXI.

Figure 2. Example of a quipu available at http://www.thefreedictionary.com / quipus.

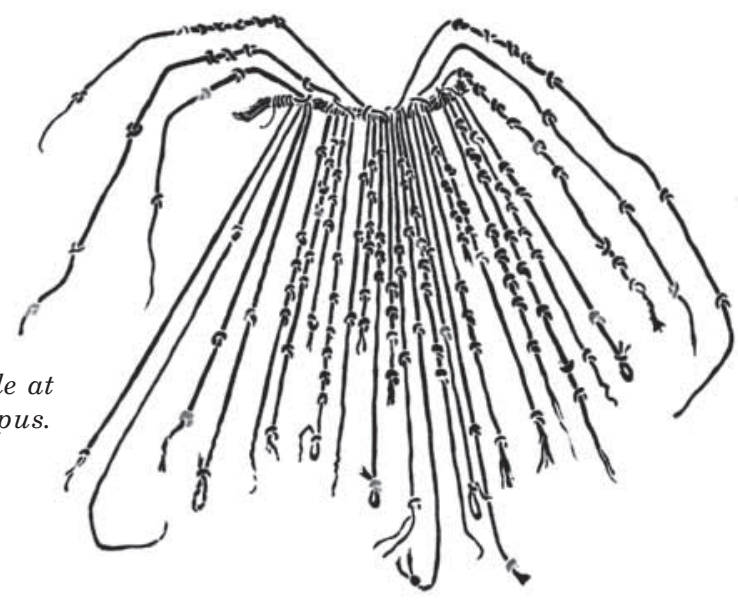

That way the Incas knew how many people lived in each settlement and in the entire state, what was their distribution by sex, age, marital status, capacity for work and state of health, how many men were to go on military campaigns and how many to public forced labour jobs. Naturally, they also knew in what quantity anything was produced, where it was stored and how much of it was consumed. The accounting was so accurate and the retrieval of information so swift that the Spanish conquistadors refused to believe it and preferred 
to accredit it to the powers of evil (on chronicles see, e.g., Garcilaso 1988; Acosta 1991: 88-90; Cobo 1996: 94, 99, 142, 253-254; on research see, e.g., Valcárcel n.d.: 13-85; Busto Duthurburu 1981: 136-139; Espinoza 1990: 422424; D'Altroy 2003: 15-19).

\section{THE ADVANTAGES OF THE QUIPU}

The elements of the quipu enabled the recording of large quantities of statistical, possibly also verbal information. On a very large quipu, the scope of information was practically infinite. Trained quipucamayocs were able to quickly and accurately decode the information stored in a quipu.

As already mentioned, a quipu could be read by officials who had received special training. They were the only ones who knew how to store and retrieve information. They were not allowed to err, and their social contacts were limited. The contents of the information or message stored in a quipu, therefore, remained a secret to an outsider, which also solved the security problem.

The Incas had no means of transportation and carriage. Messages were forwarded by means of running couriers (chasqi), who passed them on in post stations according to a special relay system. Letters written on tree leaves, for instance, would have quickly turned useless under such treatment. Furthermore, that would have required very large quantities of tree leaves, which, under the poor natural conditions of the Peruvian coastal and mountainous areas would not have been practical. Thus, quipu cords were more suitable for information exchange.

The Incas were pragmatic rulers. A message written to the emperor was obviously supposed to contain a plethora of titles and addresses - essentially useless information, which would have reduced the substantial, informational value of the letter. The cords and knots of a quipu comprised condensed statistical information and were therefore more practical in terms of administrative capacity than a written message could have been.

For a whole century, the Incas waged wars of conquest, demanding strong discipline and maximal accounting of the resources: the number of inhabitants and workers in the provinces and villages, the quantity of production put out by the workers and of the tax, the number of soldiers in military units and garrisons, the amounts of different types of weaponry, the number of carriers and auxiliary workforce, the size of enemy troops communicated by scouts, the production and training requirements arising from all that. The quipu as a statistical aid therefore provided a huge advantage in governing the empire compared to a writing system. 
Nevertheless, to use the quipu to directly record historical events and maintain the continuity of the cultural tradition would probably have been complicated. The Incas solved that problem by means of the institution of memorizers. Under the supervision and censorship of the authorities a number of people with outstanding memory capacities were trained. They were to memorize specific narratives and reproduce them verbatim as required. In addition to them, so-called "living copies" were sent to different parts of the empire. By means of such a service the required ideological training was provided and public attitudes were moulded in the Incan state. Yet one can be certain that the quipu as a statistical device served as an aid to those knowledgeable people at least in remembering numerical information, which at the same time could not be distorted.

Thus, the quipu was far more useful to the rulers of the Incan Empire as a tool of power than any traditional writing system could have been.

It is probable that the use of quellqa was banned by the order of Pachacutec Yupanqui or Tupac Yupanqui around 1470 in connection with the subjugation of the powerful Chimú state in northern Peru and among its allies. The aim of the Incas was to prevent a wider spread of this system of information exchange, which was readily available and convenient to use.

In its stead, the Incas favoured the use of the traditional mnemotechnical device quipu, which was known to the previous civilisations in Peru, because its practical uses were limited. The teaching, learning and use of the quipu were subjected to the strict control of a special organ of government. This served the political interests of the early totalitarian state.

\section{ACKNOWLEDGEMENTS}

The article has been supported by grant no. 5374 of the Estonian Science Foundation.

\section{COMIMENTS}

${ }^{1}$ Has the meaning of 'script' also in modern Quechua. Hereinafter, the word form provided in the dictionary Diccionario Español-Quechua / Quechua-Español (s. a.: 163) is used. Dictionary by Malaga (1988: 33) gives the form ccellcca. Parallel forms used in literature are kilca, quillca, quellcca, kellca, qillka, etc. 
2 Today, it accommodates the principal city in north Peru, Trujillo, in the immediate vicinity of which lie the ruins of Chanchan, the capital city of the Chimú kingdom (see also Busto Duthurburu 1988: 191-222).

${ }^{3}$ The climate of the coastal strip of Peru is very varied. The coast represents a desert area split by some fifty fertile river valleys. The southern and central regions (Paracas, Nazca) are very dry and without precipitation, while the northern regions (Moche, Vicus) are very humid.

${ }^{4}$ The most common word to signify the mnemotechnical knot-script of the Incas. Parallel forms used in literature are 'kipu', 'qquipu', 'khipu', ' $k$ 'ipu, etc.

\section{REFERENCES}

Acosta, José de 1991. Das Gold des Kondors: Berichte aus der Neuen Welt 1590 und Atlas zur Geschichte ihrer Entdeckung = Historia Natural y moral de las Indias (1590). Herausgegeben und übertragen von Rudolf Kroboth, Peter H. Meurer, Cornelis van Wytfliet. Stuttgart \& Wien: Edition Erdmann in K. Thienemanns Verlag, pp. 88-90.

Barthel, Thomas S. 1977. Writing Systems. In: Thomas A. Sebeok (ed.) Native Languages of the Americas, Vol. 2, New York: Plenum Press, pp. 27-31.

Berezkin, Yurii 1983. Mochika:Tsivilizatsiia indeitsev severnogo poberezh'ia Peruv I-VII vv. Leningrad: Nauka.

Busto Duthurburu, José Antonio del 1981. Perú incaico. Lima: Librería Studium Editores.

Busto Duthurburu José Antonio del 1988. Perú preincaico. Lima: Librería Studium Editores.

Calancha, Antonio de la 1976. Crónica moralizada, 3 [1638]. Edición de Ignacio Prado Pastor. Lima: UNMSM.

Cobo, Father Bernabé 1996. History of the Inca Empire = Historia del Nuevo Mundo [1653]. 5th ed. Transl. and ed. by Roland Hamilton from the holograph manuscript in the Biblioteca Capitular y Colombina de Sevilla. Foreword by John Howland Rowe. Austin: University of Texas Press.

D’Altroy, Terence N. 2003. The Incas. Oxford: Blackwell Publishing.

Diccionario Español-Quechua/Quechua-Español. N.d., Vol. 1, Lima: EGSELURIMPEGUSA, p. 163.

Espinoza Soriano, Waldemar. 1990. Los Incas. Economía, sociedad y estado en la era del Tahuantinsuyo. 2nd ed. Lima: Amaru Editores.

Garcilaso de la Vega, Inca 1988. Comentarios Reales de los Incas [1609], Vols. 1-3. Lima: Editorial Mercurio S.A.

Jara, Victoria de la 1970a. La solucion del problema de la escritura peruana. Arqueología y Sociedad, No. 2, Lima.

Jara, Victoria de la 1970b. Los nuevos fundamentos para el estudio integral de la escritura peruana. Revista de la Escuela Superior de Guerra, No. 67, Lima.

Málaga, C.E. 1988. Diccionario de la lengua Quechua al Castellano. Lima: Editorial Mercurio S.A., p. 33. 
Montesinos, Fernando de 1957. Memorias Antiguas, Historiales y Politicas del Perú [1642]. Cuzco: Universidad de S.A.A.

Radicati di Primeglio, Carlos 1984. El secreto de la quilca. Revista de Indias, Madrid, 44 (173), pp. 11-60.

Valcárcel, Carlos Daniel, n.d. Historia de la educación incaica. Lima: Libreria Importadora, Editora y Distribuidora. 